\title{
Effect of Consortium of Endophytic Nitrogen Fixing Bacteria in Suru- Sugarcane on Yield at Agricultural Research Station-Kasbe-Digraj
}

\author{
B. D. Chavan*, M. V. Chavan, A. D. Deshmukh and A. G. Durgude \\ Department of Soil Science and Agricultural Chemistry, Mahatma Phule Krishi Vidyapeeth, \\ Rahuri (MS) - 413722 \\ *Corresponding author
}

\section{A B S T R A C T}

\section{Keywords}

Sugarcane,

Consortium,

Endophytes

Article Info

Accepted:

04 March 2020

Available Online:

10 April 2020
A field experiment was conducted at Agricultural Research Station-KasbeDigraj (Dist.-Sangli) Maharashtra, (India) during 2013-15. It was laid out in Randomized Block Design with four replication and six treatments. There were various levels of nitrogen $(100 \%, 50 \%, 25 \%$ and $0 \%)$ with $\mathrm{P}_{2} \mathrm{O}_{5}, \mathrm{~K}_{2} \mathrm{O}$, PSB, FYM and foliar application of consortium of endophytic nitrogen fixing bacterial with and without combination and set treatment of Acetobacter diazotrophicus. The results of experiment revealed that the application of $25 \% \mathrm{~N}+$ foliar application consortium of endophytic bacteria@3 L ha ${ }^{-1} 60$ days after planting of sugarcane was found beneficial for saving of 75 per cent nitrogen with increase in yield of surusugarcane (Phule-265).

\section{Introduction}

Sugarcane is a sub-tropical crop which is botanically known as Saccharum officinarum $(2 \mathrm{n}=80)$. Sugarcane is the pride crop of Maharashtra State and plays a vital role in a Agriculture economy. It is long duration i.e., perennial gramminous plant that undergoes a series of interdependent but fairly distinct growth phases during its life time. These phases are germination, tillering (together called formative phase), vegetative grand growth, flowering or tasseling and ripening or maturity. It is favourably adaptable to various soil conditions.

Nitrogen is an essential element for plant growth \& development a limiting factor in plant growth. It represents about $2 \%$ of the total dry matter. Nevertheless, plants cannot directly access nitrogen gas, which makes up about $80 \%$ of the atmosphere. Plants absorb the available nitrogen in the soil through their roots in the form of nitrogen and the dependence of crop growth on this element have spawned a massive on this element 
industry worldwide (Dobermann, 2007 and Westhoff, 2009).

Endophytes nitrogen fixing bacteria are associative type nitrogen fixers. Mostly iyt is present in sugar containing plants, but they also present in non-sugar plants. Pennisetum purpureum, Ipomea batatas (Dobereiner and Reis, 1993), Coffea Arabica (Jimenez Salgado et al., 1997), Eleusine coracana (Loganathan and Nair, 2003) and Ananas comosus (Tapia - Hernandez et al., 2000) these are some examples of non-sugar plants in which endophytic bacteria stay.

Consortium of endophytic bacteria includes various bacteria like, Acetobacter spp., Agrobacterium spp., Burkhloderia spp., Azospirillum spp., Herbaspirillum spp., Azoarcus spp.etc. Endophytes are defined as microorganisms living inside the plant organs and tissues without causing disease symptoms, have become highly interesting models to study plant microbe interactions (More, 2012).

Keeping these points in consideration, field trial was conducted to enhance the yield and quality of suru-sugarcane using $25 \% \mathrm{~N}$ along with consortium of endophytic nitrogen fixing bacteria.

\section{Materials and Methods}

The experiment was conducted at Agricultural Research Station-Kasbe-Digraj (Dist.-Sangli) Maharashtra, (India) during 2013-15, the soil was clayey in texture, moderately alkaline in reaction, medium in available nitrogen, phosphorus and sufficient in available potassium. Total 6 treatments including absolute control replicated 4 times. The experiment consists of different levels of nitrogenous fertilizer viz. 0, 25, 50 and $100 \%$ of RD along with and without foliar application of consortium endophytic nitrogen fixing bacteria@3 $\mathrm{L} \mathrm{ha}^{-1}$ or Acetobacter diazotrophicus@2.5 L ha ${ }^{-1}$ with $500 \mathrm{~L}$ water in treatments. The crop was raised following recommended agronomic practices. The recommended dose of chemical fertilizers were applied @250:115:115 kg NPK ha ${ }^{-1}$ in four splits as per recommendation. Intercultural operations like weeding, spraying of insecticides, fertilizer application and schedule of irrigation for suru-sugarcane crop was carefully followed. The crop variety used was CoM- 0265. The data obtained was carefully analyzed and appropriately interpreted as per the methods described in "Statical Methods for Agricultural Workers" by Panse and Sukhatme, (1985).

\section{Results and Discussion}

The results narrated in Table 1 indicate significant impact of consortium of endophytic nitrogen fixing bacteria on top, cane and CCS yield of suru-sugarcane. Significantly highest top and cane yield of suru- sugarcane were noted in RDF, but treatment $25 \% \mathrm{~N}+$ consortium of endophytic nitrogen fixing bacteria was found statically at par. Lowest top and cane yield were obtained in treatments $T_{1}$. These results are also corroborate with reports of More (2012) as they revealed that this might be due to consortium of endophytic bacteria, which may worked with plant system by utilizing their source of energy as sugar from sugarcane plant and assimilated the nitrogen within the plant, which may be immediately utilized for growth and development of sugarcane plant. Thereafter, Oliveira et al., (2002) noted that the fresh cane weight of sugarcane was significantly increased as compared to uninoculated control plot. Muchow et al., (1996) also reported that increased cane yield with increasing levels of nitrogen application and lowering the commercial cane sugar. 
The data of cane and top yield of suru sugarcane as influenced by different treatments are presented in the table. The cane yield $\left(114.34 \mathrm{t} \mathrm{ha}^{-1}\right)$ and top yield $(10.27 \mathrm{t}$ $\left.\mathrm{ha}^{-1}\right)$ of sugarcane were significantly increased in treatment $\mathrm{T}_{4}(25 \% \mathrm{~N}+$ consortium of endophytic bacteria foliar spray) over all the treatments.

Table.1 Yield of suru-sugarcane as influenced by different treatments (ARS Kasbe-Digraj)

\begin{tabular}{|c|c|c|c|}
\hline \multirow{2}{*}{\multicolumn{2}{|c|}{ Treatments }} & \multicolumn{2}{|c|}{ Yield of sugarcane $\left(\mathrm{t} \mathrm{ha}^{-1}\right)$} \\
\hline & & Cane & Top \\
\hline $\mathbf{T}_{1}$ & Absolute control & 99.04 & 8.90 \\
\hline $\mathbf{T}_{2}$ & $\operatorname{RDF}(100 \% \mathrm{~N})$ & 105.50 & 9.51 \\
\hline $\mathbf{T}_{\mathbf{3}}$ & $\begin{array}{l}50 \% \mathrm{~N}+\text { Set treatment of Acetobacter } \\
\text { diazotrophicus }\end{array}$ & 101.16 & 9.10 \\
\hline $\mathbf{T}_{4}$ & $25 \% \mathrm{~N}+$ Consortium of endophytic bacteria & 114.34 & 10.27 \\
\hline $\mathbf{T}_{5}$ & $0 \% \mathrm{~N}+$ Consortium of endophytic bacteria & 93.28 & 8.38 \\
\hline $\mathbf{T}_{6}$ & $\begin{array}{l}0 \% \mathrm{~N} \text { Without consortium of endophytic } \\
\text { bacteria }\end{array}$ & 96.62 & 8.76 \\
\hline & SE $( \pm)$ & 2.100 & 0.198 \\
\hline & CD@ $9 \%$ & 6.329 & 0.597 \\
\hline
\end{tabular}

The increase in crop productivity may be due to low nitrogen fertilizer application with increased growth of nitrogen fixing bacteria. The similar results were also reported by Muthukumarasamy et al., (1999), Rakkiyappan et al., (2001), Bhalerao et al., (2005), Anitha and Thangaraju (2010).

It is concluded that, the application of $25 \% \mathrm{~N}$ + foliar application consortium of endophytic bacteria@3 L ha ${ }^{-1} 60$ days after planting of sugarcane was found beneficial for saving of 75 per cent nitrogen which increase in available $\mathrm{N}$ content in soil, stage wise total $\mathrm{N}$ concentration in leaves and cane, uptake of nutrient, nitrogen use efficiency, $\mathrm{B}: \mathrm{C}$ ratio (except $\mathrm{T}_{1}$ ) and yield of suru sugarcane (Phule-265).

\section{References}

Anitha, K.G. and Thangaraju, M. 2010. Influence of $\mathrm{N}$ fertilization on colonization and activity of Gluconacetobacter diazotrophicus. in
Sugarcane. J. Agro. Crop Sci. 1(1): 611.

Bhalerao, V.P., Jadhav, M.B. and Bhoi, P.G. 2005. Substitution of chemical fertilizers using different organic and studying their effects on soil properties, nutrient, uptake yield and quality of sugarcane. Co-operative. Sug. 36(1): 903-908.

Chapman, L.S. 1994. Fertilizer N management in Australia. Proceedings Australian Society of Sugarcane Technology Conf. pp 83-92.

Dobermann, A. 2007. Nutrient use efficiencymeasurement and management in a time of new challenges. In: Proceedings of the IFA International Workshop on Fertilizer Best Management Practices. Fertilizer Best Management Practices, 7-9 March 2007, Brussels, Belgium. International Fertilizer Industry Association, 1-28.

Dobereiner, J. and Reis, V.M. 1993. Endophytic diazotrophs in sugarcane, cereals and tuber plants, in New 
Horizons in nitrogen fixation. Springer 671-676.

Jimenez-Salgado, T., Fuentes-Ramírez, L.E., Tapia-Hernandez, A., MascaruaEsparza, M.A., Martínez-Romero, E. and Caballero-Mellado, J. 1997. Coffea arabica L., a new host plant for Acetobacter diazotrophicus, and isolation of other nitrogen-fixing acetobacteria. Applied and Environmental Microbiology 63, 36763683.

Loganathan, P. and Nair, S. 2003. Cropspecific endophytic colonization by a novel, salt-tolerant, $\mathrm{N}_{2}$-fixing and phosphate-solubilizing

Gluconacetobacter sp. from wild rice. Biotechnology Letters 25, 497-501.

More R.R. 2012. Sugarcane Research Report of Vasantdada Sugar Institute by Division of Agricultural Sciences and Technology. pp. 354-364.

Muchow, R.C., Robertson M.J., Wood, A.W. and Keating, B.A. 1996. Effect of nitrogen on the time-course of sucrose accumulation in sugarcane. Field Crop Research 47, 143-153.

Muthukumarasamy, R., Revathi G. and
Lakshminarasimham, C. 1999. Influence of $\mathrm{N}$-fertilization on the isolation of Acetobacter diazotrophicus and Herbaspirillum spp. From Indian sugarcane varieties. Biology and Fertility of Soils 29, 157- 164.

Oliveira, A.L.M., Urquiaga, S., Dobereiner, J. and Baldani, J.I. 2002. The effect of inoculating endophytic $\mathrm{N}_{2}$ fixing bacteria on micropropagated sugarcane plants. Plant and Soil 242, 205-215.

Panse, V.G. and Sukhatme, P.V. 1985. Statistical Methods for Agriculture Workers, ICAR Publ., New Delhi.

Tapia-Hernandez, A., Bustillos-Cristales, M.R., Jimenez-Salgado, T., Caballero Mellado, J. and Fuentes-Ramirez, L.E. 2000. Natural endophytic occurrence of Acetobacter diazotrophicus in pineapple plants. Microbial Ecology 39, 49-55.

Westhoff, P. 2009. The economics of biological nitrogen fixation in the global economy. Nitrogen fixation in crop production. Agronomy Monograph No. 52. Madison, WI: American Society of Agronomy 309-328.

\section{How to cite this article:}

Chavan, B. D., M. V. Chavan, A. D. Deshmukh and Durgude, A. G. 2020. Effect of Consortium of Endophytic Nitrogen Fixing Bacteria in Suru- Sugarcane on Yield at Agricultural Research Station-Kasbe-Digraj. Int.J.Curr.Microbiol.App.Sci. 9(04): 280-283. doi: https://doi.org/10.20546/ijcmas.2020.904.034 